\title{
Universal access to clean cookstoves: evaluation of a public program in Peru*
}

Joan Calzada, Universitat de Barcelona: calzada@ub.edu

Alex Sanz, Universitat Autonoma de Barcelona: Alex.Sanz@uab.cat

\begin{abstract}
The use of biofuels for heating and cooking is the main cause of indoor air pollution in developing countries, and one of the main causes of acute respiratory infections. To tackle this problem, in 2012, the Peruvian Government created the FISE Program, which subsidizes the replacement of traditional stoves with gas cookstoves. This paper describes the challenges faced during the implementation of the FISE, such as the selection of beneficiaries and the creation of a national network of suppliers for the delivery of liquefied petroleum gas (LPG) cylinders. Using a dataset with information collected from five districts in the department of Ayacucho in 2015, we apply propensity score matching at the household level to evaluate the effects of the program. We show that the FISE favored the adoption of the LPG cookstoves, but that many households still combine their use with traditional cookstoves. We find no evidence that the use of LPG stoves has reduced respiratory problems in the beneficiary households; however, the program has been found to increase the use of LPG stoves for boiling water, which may reduce the exposition of child in beneficiary households to water-related diseases.
\end{abstract}

Keywords: Cookstoves, LPG, Subsidies, Indoor Air Pollution, Health, FISE Program, Peru.

JEL: D12, L51, O12, O13, Q53, Q55.

* In conducting this study we have received support from several Peruvian public institutions, including the Ministry of Energy and Mines (MINEM) and the Fondo de Inclusión Social Energético (FISE). We are especially grateful for comments and suggestions received from two anonymous referees and from Victor Murillo, Johnny Gonzalez, Antonio Estache, Joan Ramon Borrell, and José Luis Jiménez. We also acknowledge financial support from the Spanish Ministry of Economy and Competitiveness (ECO2015-69193R) 


\section{Introduction}

A large percentage of the world's population does not have access to modern energy sources. Indeed, figures show that 1.26 billion people are still without access to electricity and more than twice that number use biomass for cooking (Bonjour et al., 2013). This creates a major health problem in developing countries, since pollutants emitted by the traditional solid fuels used in inefficient stoves generate indoor air pollution (IAP), which is a major factor of premature death (WHO, 2006a; Lim et al., 2012). According to the WHO (2005), 19 percent of mortality in infants under the age of 5 is caused by acute respiratory infections (ARI), making it the second highest cause of infant mortality worldwide. In Peru, around 6.4 million people do not use modern, clean energy sources to cook. Moreover, in rural areas more than 50 percent of households usually use wood, charcoal or kerosene for cooking. As a consequence, lower respiratory tract infections are the leading cause of morbidity and mortality in Peruvian children under the age of 5 . Around 2,400 children below this age die every year because of these infections, representing 16 percent of the country's total child mortality (Global Burden of Disease, 2010).

Recognition of the importance of IAP has led international organizations and national authorities in many developing countries to make significant efforts to replace traditional firewood stoves with more efficient, healthy cookstoves. Organizations that include the Global Alliance for Clean Cookstoves (GACC), the World Bank and the EnDev Project (Energizing Development) currently fund programs to promote the use of clean kitchens in developing countries, mainly in Africa and Asia, but also in Latin America. Examples of such programs implemented at the national level are the National Biomass Cookstoves Program, introduced in India in 2009 with the aim of providing 
160 million households with improved cookstoves; the Mines Energy Policy 20132027, promoted in Guatemala with the goal of installing 100,000 modern cookstoves (GACC, 2014); the Chinese National Improved Stove Program initiated in the 1980s; and, the China Clean Stove Initiative, launched in 2012 to scale up access to clean cooking and heating stoves in rural areas (Barnes et al., 1994; Barnes et al., 2012; Vahlne and Ahlgren, 2014). Most of these programs support the substitution of traditional stoves with others of improved design that permit the use of more efficient fuels, such as charcoal (World Bank, 2011). ${ }^{1}$ But there are few examples of nationwide programs that promote the adoption of cleaner solutions such as electricity, liquefied petroleum gas (LPG), or other cooking gasses with lower levels of air pollution exposure. The advantages of these modern cookstoves are that they reduce toxic emissions considerably; reduce the time spent cooking and collecting fuel; can be quickly turned on and off; and, allow the heat to be regulated. However, due to the price and the difficulties in accessing these energies in some regions, low-income households typically use them in combination with biomass fuels (Barnes et al., 2012). ${ }^{2}$

In this paper we analyze the FISE Program (Fondo de Inclusión Social Energético), created in 2012 by the Peruvian Government with the aim of enhancing the access of low-income households to clean, efficient energy. One of the most important actions developed by the program was the promotion of LPG cookstoves. To achieve this objective, the FISE offers eligible households free delivery of LPG cookstoves and a monthly discount voucher that reduces the price of LPG cylinders by half. Since its introduction in 2012, the FISE has benefited more than 1.5 million households around

\footnotetext{
${ }^{1}$ Bensch and Peters (2012) define improved cookstoves as "sophisticated bricked stoves with chimneys leading the smoke out of the kitchen or very simple portable clay or metal stoves that just improve the heating process".

2 A review of the literature analyzing the adoption of improved, clean cookstoves can be found in Barnes et al. (2012), Puzzolo et al. (2016), Pope et al (2017), and Mehetre et al. (2017).
} 
the country, especially those in areas suffering extreme poverty. Moreover, the program has favored the creation of a large market for LPG cylinders, which today are commercialized in virtually every district of the country.

The objectives of our research are two-fold. First, we analyze the main characteristics of the FISE program and the challenges it faced during its implementation. A common criticism of subsidy programs of this kind is that they have a regressive effect, benefiting middle and high-income households that already have access to the service or which are located in urban areas. Taking this into account, we will examine the strategy followed by the FISE to conveniently select the households that can participate in the voucher scheme.

Our second objective is to evaluate the impact of the FISE voucher on the beneficiary population. Recent studies have questioned the benefits of public programs promoting the replacement of traditional cookstoves on the grounds that the recipients of the new stoves do not value or use them enough and fail to maintain them properly (Barnes et al., 1994; Miller and Mobarak, 2013; Bensch and Peters, 2012 and 2015; Hanna et al., 2016). Using a data set from a survey conducted in 2015 by the FISE in the district of Ayacucho (Huamanga), we analyze if the FISE voucher scheme has incentivized users to switch from traditional cookstoves to LPG stoves, and we investigate if the program has alleviated the respiratory problems of the beneficiary population.

The rest of the paper is organized as follows. Section 2 reviews the literature that has studied the programs promoting the adoption of improved cookstoves in developing countries. Section 3 explains the characteristics of the FISE program. Section 4 presents the data set and the methodology applied in the empirical analysis. Section 5 shows the results of this analysis. Finally, section 6 concludes. 


\section{Background}

There is a broad consensus in the literature that one of the main determinants of biomass replacement in developing countries is the households' socio-economic situation. According to the "energy ladder theory", households substitute traditional fuels with more efficient ones when their socio-economic situation improves (Hosier et al., 1987). Specifically, the theory envisages a three-stage replacement process: initially, poor households rely on biomass; as their income increases they switch to transition fuels, such as charcoal, coal and kerosene; and, finally, households with a higher income adopt clean fuels, such as LPG cylinders, electricity or natural gas.

A similar path describes the use of fuels for cooking, with households combining different energy sources depending on their economic situation and specific characteristics (Ruiz-Mercado et al., 2011). Previous studies have shown that a household's choice of energy depends on its income (Heltberg, 2005; Bansal et al., 2013; Arthur et al., 2010; Hanna and Oliva, 2015; Hiemstra-van der Horst and Hovorka, 2008), fuel prices (Jain, 2010), household size (Liu et al., 2003; Nnaji et al., 2012), the maintenance costs of the asset (Chaurey et al., 2004; Barnes et al., 2010; Burwen and Levine, 2012; Miller and Mobarak, 2013; Hanna et al. 2016), and the distance to markets (Elias et al., 2005).

Another strand of the literature has examined the relationship between the choice of cooking fuel and the educational level of household members. Heltberg (2004), in an analysis that includes Brazil, Ghana, Guatemala, India, Nepal, Nicaragua, South Africa and Vietnam, shows that the mother's education is positively related to the probability of a household using modern fuels. In rural India, Pandey and Chaubal (2011) report that the number of educated women aged between 10 and 50 in a household and the average educational level of the household are associated with the likelihood of that 
household cooking with cleaner fuels. Finally, a range of behavioral and cultural factors, including cooking practices, taste of food and the time required for cooking with each type of stove, also seem to affect a household's fuel choice. For example, Masera et al. (2000) show that in rural Mexico the population continued to use fuelwood after gaining access to modern fuels, arguing that cooking tortilla with gas requires more time and affects the taste. Similarly, the IEA (2006) reports that, in India, households prefer to bake bread in wood stoves.

Our paper is also related to the literature analyzing the health benefits of using clean fuels. In a study conducted in Kenya, the Sudan and Nepal, the WHO (2006b) finds that the use of clean energy had health benefits and reduced the medical costs due to a reduction in the number of days of sickness in both adults and children. Other studies have shown that modern fuels and improved cookstoves minimize the health risks associated with air pollution (Smith-Sivertsen et al., 2009; Parikh, 2011). However, in an analysis of a large-scale randomized trial, Hanna et al. (2016) show that while improved cookstoves initially reduced smoke inhalation, they did not produce changes in health outcomes after two years, as maintenance (e.g. cleaning of chimneys) and usage rates declined.

Interestingly, a number of papers specifically analyze the adoption of gas devices. Akpalu et al. (2011) report that Ghana's favorite fuel is LPG, especially in coastal areas. Kojima et al. (2011), in an analysis of 10 countries, show that an increase in the educational level of the population and an increase in the price of alternative fuels boost the use of LPG stoves in the period analyzed. Other papers have shown that the high costs of modern fuels prevent people from adopting them fully (Davis, 1998; Elias et al., 2005). A further hindrance to the expansion of LPG cookstoves concerns the system of commercialization. Unlike other fuels, such as kerosene or firewood, LPG has to be 
purchased in large cylinders, which may dissuade people from using it, especially members of poor households (Leach, 1992; Masera et al., 2000).

Finally, very few papers have analyzed the use of subsidy schemes to promote the expansion of LPG cookstoves. Arze del Granado et al. (2012) examine 20 developing countries between 2005 and 2009 and find that LPG subsidies were largely captured by society's upper classes. On the other hand, Ouedraogo (2006) analyzes the factors determining urban household energy choices in Burkina Faso, and finds that LPG and LPG cookstove subsidies can significantly reduce the use of fuelwood.

\section{The FISE Program: implementation and characteristics}

The FISE program was created in 2012 with the aim of enhancing the access of lowincome households to clean, efficient energy. One of its objectives is to promote the use of LPG stoves, by providing discount vouchers that reduce the price of LPG cylinders. This section explains the main characteristics of this subsidy scheme and how it has been implemented.

\subsection{Program description}

In 2012, the Peruvian Ministry of Energy and Mines (MINEM) approved the Plan de Acceso Universal a la Energía 2013-2022 to meet the energy needs of the most vulnerable sectors of the population. ${ }^{3}$ The objective was to provide universal access to energy and to increase energy efficiency. One of the projects promoted under the plan

\footnotetext{
${ }^{3}$ Ley $N^{\circ} 29852$ del 13 de abril del 2012, del Ministerio de Energía y Minas, created the Fondo de Inclusión Social Energético (FISE). See Banal et al. (2017) for an analysis of the recent energy policy in Peru.
} 
was the Fondo de Inclusión Social Energético (FISE), a universal service fund aimed at promoting access to and the use of basic energy services among the low-income population.

The FISE program has developed several actions, ${ }^{4}$ but one of its main objectives is to subsidize access to LPG cookstoves among the households located in the poorest districts of Peru. To achieve this goal, it offers a monthly discount voucher of 16 nuevos soles to buy LPG cylinders (the value of the vouchers has remained unchanged since 2012). As the price of a 10-kg LPG cylinder is 32 nuevos soles, a beneficiary household can purchase an LPG cylinder at zero cost by combining the vouchers for two months. Indeed, this has become the widespread practice.

Since its introduction, the FISE discount voucher system has been managed by OSINERGMIN (Organismo Supervisor de la Inversión en Energía y Minería), the national regulatory agency for the energy sector. The MINEM regulates the delivery of LPG cylinders, defines the potential beneficiaries of the vouchers and develops mechanisms to universalize the use of LPG. It also prioritizes the projects to be implemented and defines the strategy for the sector in the medium term. OSINERGMIN, in turn, manages the program and decides how to distribute the funds.

\footnotetext{
4 The general objectives of the FISE are to (1) promote the use of natural gas by financing the construction of connections to the households; (2) universalize access to energy services in rural and remote communities; (3) promote the use of LPG cookstoves among low income households; and (4) guarantee the same price for the electricity service to all households, regardless of their location and the type of distributor employed.
} 
The FISE is financed primarily by surcharges established on the prices paid by large electricity consumers, large suppliers of derived liquid hydrocarbon and natural gas liquids, and large consumers of natural gas. In 2014 , the FISE raised $\$ 147,228,005$, with 82 percent of these revenues being obtained from the above consumers.

\subsection{Beneficiaries of the program}

Beneficiaries of the FISE discount voucher must meet various requirements: (1) they must live in a district with a high level of poverty; (2) have an LPG stove, although the MINEM provides free stoves for households that do not have one; (3) have an electricity consumption below $30 \mathrm{kWh}$ per month; (4) not have access to the natural gas network; (5) have an income below 18,000 nuevos soles per year (around \$5,500) and (6) have a residence constructed from poor materials. ${ }^{5}$

These requirements were established by the FISE after running a pilot project in 2012 in the province of La Convención (Cusco). During this pilot, it was noted that some high income households were classified as being eligible for the voucher scheme. As a result, the FISE introduced a limit on household income and reduced the maximum electricity consumption from 100 to $30 \mathrm{kWh}$ per month. Additional measures were introduced to prevent owners of several houses from receiving more than one voucher, and to allocate the vouchers corresponding to rented households to the tenants rather than to the owners.

Today, the FISE identifies the potential beneficiaries of the voucher system by using a poverty map drawn up by the Peruvian statistical office (Instituto Nacional de

\footnotetext{
${ }^{5}$ Households are not eligible for the voucher if the predominant material used in the construction of the walls of their house is brick or concrete blocks, if the house has more than one floor, or if the dominant material in the floor is parquet, polished wood, asphalt sheeting, vinyl, terrazzo, or similar.
} 
Estadística e Informática, INEI). This map combines information generated by several institutions to calculate per capita household spending and creates a poverty and inequality index for the Peruvian districts. Households in each district are classified into seven strata according to the Sistema de Focalización de Hogares (SISFOH). ${ }^{6}$ Strata 1 and 2 correspond to households classified as extremely poor (20 percent poorest population); strata 3,4 and 5 correspond to poor households that do not reach an extreme poverty threshold (30 percent of the population); and strata 6 and 7 include non-poor households (50 percent of the population). Only households in strata 1-4 are eligible to apply to participate in the voucher scheme.

\subsection{Project management}

The management of the voucher scheme has been delegated in part to the regional electricity distributors, which have a regular relationship with the households and can determine their electricity consumption. These distributors have a census that contains all the households within their concession areas that meet the participation criteria. ${ }^{7}$ These households receive either a printed voucher stapled to their electricity bill or a digital voucher sent via SMS to their mobile phones. Households can then use the vouchers to purchase LPG cylinders from authorized LPG suppliers. Figure 1 depicts how the discount voucher system works.

\footnotetext{
${ }^{6}$ The SISFOH collects information about the households' socioeconomic characteristics and calculates a poverty index that allows households to be classified into seven strata. Electricity distributors verify that applicants satisfy all the requirements to participate in the program and that they are registered in the SISFOH.

${ }^{7}$ FISE uses the data from the electricity distributors to ensure that the consumption requirements are met. Households do not receive a voucher in the months in which their average electricity consumption exceeds $30 \mathrm{kWh} / \mathrm{month}$, and in the years in which they exceed the income limit.
} 


\section{Insert Figure 1}

\section{Insert Figure 2}

\section{Insert Figure 3}

At the beginning of 2016, the FISE was operational in 1,791 districts (97.5 percent of the total) and the vouchers were distributed to $1,472,852$ households (Figure 2). It was also present in all the country's regions, with Puno having the largest number of beneficiaries, with 202,139 households. Between July 2012 and March 2016, the number of LPG suppliers participating in the program rose from 5 to 3,903 (Figure 3). ${ }^{8}$ This increase can be explained in part by the introduction of the "digital voucher" in 2013, created in response to the management problems caused by the printed vouchers stapled to the electricity bills. ${ }^{9}$ In the first months after the creation of the program, the LPG suppliers had to wait more than 15 days to receive the value of the printed vouchers, a situation that discouraged their participation. Some suppliers sold the LPG cylinders with an extra cost in order to accept the vouchers, while others refused to accept them at all. This situation created discontent among both consumers and suppliers, and led many suppliers to unsubscribe from the program in mid-2013. ${ }^{10}$ The digital voucher was created in July 2013 to eliminate these problems and since then the number of suppliers participating in the program has increased greatly. Indeed, digital vouchers mean LPG suppliers receive the amount of the voucher at the time of the

\footnotetext{
${ }^{8}$ There are two types of Authorized LPG Agents: LPG bottling plants and stores. The stores sign an agreement with the electricity distributors in order to become Authorized Agents permitted to exchange FISE vouchers.

9 The digital voucher has received several industry awards. At the national level, it won the Business Creativity Contest organized by the Peruvian University of Applied Sciences (UPC), and it received the Good Practices in Public Administration award for 2017. Internationally, it has received the recognition of the Organization of American States (OAS) and Asia-Pacific Economic Cooperation (APEC).

${ }^{10}$ Moreover, the electricity distributors would send the vouchers stapled to the electricity bills in unsealed envelopes. This resulted in some postal employees engaging in fraudulent practices.
} 
transaction. Moreover, the possibility of sending and receiving SMS messages through the mobile phones has allowed households that do not have access to electricity, or that contract this service collectively, to participate in the program.

The electricity distribution companies play a key role in managing the vouchers. Each month they send a code to the beneficiary household via an SMS (or a printed voucher stapled to their electricity bill), which can be used to pay for the LPG cylinder. When consumers buy a cylinder they send an SMS to the LPG supplier, who in turn sends another SMS to their bank to be credited with the value of the voucher. At the same time, the bank receives a transfer from the electricity distributor. Finally, the electricity companies are periodically compensated from the FISE. ${ }^{11}$

\section{Data and methodology}

\subsection{Data}

This section examines how the FISE discount voucher system can affect the decision of the beneficiary households to cook with an LPG stove, and the impact that this decision can have on the family's health. Our empirical analysis draws on information collected in a survey conducted by OSINERGMIN in April 2015 in Huamanga, one of the 11 provinces of the Department of Ayacucho. ${ }^{12}$ Huamanga has a population of 221,390 inhabitants, occupies an area of $2981.37 \mathrm{~km}^{2}$, and is divided into 16 districts, one of which is the city of Ayacucho. The average altitude of this province is around 2,500 meters. The survey was conducted in households located in five districts: Andrés Avelino Cáceres, Ayacucho, Carmen Alto, Socos and Vinchos. The treated population

\footnotetext{
${ }^{11}$ To avoid the fraudulent use of vouchers, the FISE controls the number of transactions completed by each beneficiary and by the LPG supplier. For example, the FISE is able to detect if a beneficiary exchanges more than two vouchers a month.

${ }^{12}$ The survey included neither anthropometric measurements of individual respondents nor pollution measurements inside buildings.
} 
was randomly selected from the district of Vinchos. The control group come from the other districts, but mainly from Ayacucho. The data collected contains information about 458 households, most of which are from Vinchos (193) and Ayacucho (171). These households correspond to a universe of 1,816 people.

To evaluate the program we use a matching technique, which involves comparing different outcome variables for households participating on the FISE program (treatment group) with those for households with a similar propensity to participate but that do not actually do so (control group).

One potential problem associated with matching techniques is that their results may be biased when the treated and control groups have different socio-economic characteristics. To overcome this problem, a random sample of beneficiaries was chosen for the treatment group during the design of the study. Additionally, using information from the SISFOH and the FISE databases, households not participating in the program but with similar characteristics to those participating were included as controls. Despite these measures, Table 1 reveals significant differences between beneficiary and nonbeneficiary households for some outcome variables. This is the case, for example, of access to social programs, maternal language, and the education level of the household members. One explanation for these differences is that when the households were selected information regarding household income was unavailable. Thus, the average monthly income in the group of beneficiaries was 391 nuevos soles, while in the group of non-beneficiaries it was 800 nuevos soles. As we explain below, our empirical strategy tries to address this situation.

\section{Insert Table 1}


Regarding monthly expenditures on energy, households in the beneficiary group spend less each month on electricity than those in the non-beneficiary group. There are also marked differences in monthly expenditure on LPG, suggesting that the voucher reduced spending in the beneficiary group. Recall that the objective of our empirical analysis is to determine whether the recipients of the voucher make greater use of LPG cookstoves than is made by non-beneficiaries of similar characteristics.

Table 1 also shows that in the beneficiary group households use more LPG cookstoves and fewer traditional stoves. However, the percentage of households using a combination of firewood and modern heating fuels is quite similar in the two groups. Yet, while in the group of non-beneficiaries there is a higher percentage of households that use only modern heating fuels (LPG and electricity), in the group of beneficiaries there is a higher percentage using only firewood.

There are several factors that might influence the evaluation of the program. First, beneficiary households could be affected by spillovers from non-beneficiaries. Indeed, the emissions generated by the combustion of biofuels in other households in the same village may affect the health of the participants in the program (Hanna et al., 2016). Second, the recipients of the vouchers might sell the LPG cylinders on to other households, although we have no direct evidence of this occurring in the villages examined. And third, it is possible that the beneficiary households do not actually exchange their vouchers regularly, suggesting that the effect of participating in the program on indoor pollution is underestimated. To address this possibility, our analysis 
reports results for households that exchange their vouchers at least every two months, ${ }^{13}$ and also for households that do so every month. ${ }^{14}$

\subsection{Measures to evaluate the impact of the program}

One of the objectives of our empirical analysis is to determine whether the voucher system can modify the population's cooking habits. Although the vouchers should serve as an incentive to use LPG stoves, the beneficiaries might opt to combine their use of LPG stoves with firewood or improved stoves. Taking this possibility into account, we analyze the impact of the voucher on the number of weekly meals cooked with LPG stoves.

On the other hand, we want to study the effects of the vouchers on the health of the beneficiary population. If the program is effective, the adoption of LPG cookstoves should reduce the emissions and the probability of household members suffering respiratory problems. As is frequent in the literature, the health indicator we consider is coughing or symptoms of respiratory problems in the household's primary cook (usually a woman) in the 30 days prior to the interview. In addition, we consider the number of days children missed school due to respiratory problems in the 30 days prior to the interview.

Finally, our analysis considers the effect of the voucher on a household's decision to boil water or not, something that is essential to prevent water-related diseases in rural communities. Our hypothesis is that the voucher would increase the probability of boiling the water, since this activity can be done more rapidly with LPG stoves than

\footnotetext{
${ }^{13}$ Households usually combine the vouchers for two months to obtain a 10-kg LPG cylinder for free.

14 The original sample includes 179 treated households and 279 controls. 149 households exchange vouchers every two months and 125 every month.
} 
with firewood and improved stoves. ${ }^{15}$ Thus, we consider whether beneficiary households boil water, and whether they use an LPG stove to boil water. Finally, we complement our analysis by considering whether the household's children missed school due to diarrhea in the 30 days prior to the interview.

Table 2 presents the descriptive statistics of the outcome variables analyzed, and shows significant differences between the program's beneficiaries and nonbeneficiaries. For example, on average, beneficiary households cooked 12 percent more weekly meals on their LPG stoves than were cooked by non-beneficiaries. Moreover, when we take into consideration only the beneficiaries that actually used the voucher, this figure increases to 17 percent. We also note that using the voucher is associated with a higher probability of households boiling water on an LPG stove. Finally, children from beneficiary households missed 0.17 days of school less per month than children in non-beneficiary households due to diarrhea, a difference that rises to 0.24 days when we consider beneficiary households actually using the voucher. For the rest of the variables, we do not find any significant differences between the two groups. Despite this, to compare the two sample groups properly, we need to consider households with similar socio-economic characteristics. Below, we explain the empirical strategy applied in comparing the two groups and for providing an adequate counterfactual.

\section{Insert Table 2}

${ }^{15}$ Calzada et al. (2017) analyze water provision in the rural communities of Peru. 


\subsection{Identification Strategy and Propensity Score}

The main difficulty we face in estimating the causal effect of the FISE program on the habits and health of the program's beneficiaries is that the latter were not chosen randomly. Rather, they had to apply to join the program and were then selected in accordance with their characteristics. To address this situation, in the initial stage of this study, non-beneficiary households were selected from three districts not covered by the program. ${ }^{16}$ Then, we used a propensity score technique to identify the non-beneficiaries that are more similar to the beneficiaries, in all aspects except for not being recipients of a voucher. Finally, we used matching algorithms to assign to each beneficiary a nonbeneficiary with a similar propensity score to receive a voucher. This methodology ensures we assess the effect of the voucher within a homogeneous group of households.

In order to identify possible differences between the group of beneficiaries and the group of non-beneficiaries initially selected by OSINERGMIN, we estimate a logit model that considers the probability of receiving the voucher. Table 3 shows the covariates included in this model: namely, income (in logs), having a mobile phone, access to other social programs (e.g. Cunamas, Juntos, P65, Techo Propio), access to water and sanitation within the home, characteristics of the home (if the floor is made of soil, if the walls are made of a material other than brick, and if the roof is made of a material other than concrete), having an improved and/or traditional cooking stove,

\footnotetext{
${ }^{16}$ In our order to select households as similar as possible to those in the beneficiary group a probit model was estimated, using the following variables: use of solid fuels for cooking, use of an LPG stove, the household's assets, participation in social programs (SIS, Cunamas, P65, Juntos, Techo Propio), access to electricity, electricity consumption, access to drinking water, toilets inside the house, access to fixed and mobile telephone networks, materials used to build the house, ratio of overcrowding, number of members in the household, children of school age, adults with elementary education, years of education of the household head, years of education of the spouse of the household head, unemployment of household head, illiteracy of the household head, household head's gender and education, age of household head, district, rural area.
} 
having an LPG cooking stove, monthly electricity expenses, educational levels of the household's head and his/her spouse, age of the household's head, maternal language of the household's head.

\section{Insert Table 3}

The pseudo $\mathrm{R}^{2}$ of this regression is 0.305 and several variables, including participation in other social programs, monthly electricity expenditure, and the use of a traditional cookstove, are significant. This suggests that, in spite of the efforts made by OSINERGMIN in the initial selection of the non-beneficiaries, the treated and control groups still exhibit different probabilities of participating on the FISE program. In this regard, recall that the estimated model includes the household's income as an explanatory variable, an information that was not available for OSINERGMIN when it initially selected the non-beneficiaries.

Finally we calculate the propensity score for the two groups of household, including those variables that were found as significant in the previous model. Results are reported in Figure 4. It can be seen that the database is not perfectly balanced, there being a different distribution between the two groups. Non-beneficiary households have propensity scores close to 0 , while beneficiaries present values close to one. However, if we consider the whole range of the estimated propensity score, there are enough treated and untreated households to calculate the effects of the vouchers on the beneficiary households.

\section{Insert Figure 4}




\section{Results: Nearest neighbor, kernel matching, and stratified matching}

With the results of the propensity score, we can now apply matching algorithms to determine the effect of the FISE vouchers on the outcome indicators. First, we use "nearest neighbor matching without replacement" (NN), which for each treated household compares the households in the control group with the closest propensity score, within the area of common support. A potential risk of using this method is that it may compare households with characteristics and propensity score values that are not close enough. To ensure the robustness of our results, we also use the "kernel matching algorithm", which compares each of the treated households with the average of all households in the control group. Furthermore, we use the "stratified matching algorithm", which divides households in the treatment and control groups in different strata.

For each of the outcome variables we undertake various analyses. First, we compare the whole sample of beneficiary households and non-beneficiaries. And second, we compare the beneficiaries that actually exchanged the vouchers every two months and every month with the non-beneficiaries.

\subsection{Adoption of LPG cookstoves}

Table 4 presents our results on the effects of the voucher on the use of LPG stoves for cooking. The ratio $L P G 1$ considers the whole sample of households, including those that initially did not have an LPG stove. The first column shows that households that received the voucher used LPG stoves to cook up to 33-38 percent more weekly meals 
(i.e. 7 weekly meals) than those that did not receive it. The second column focuses on households that exchanged the vouchers at least every two months to buy LPG cylinders, and shows that they used LPG stoves to cook around 34-35 percent more weekly meals than households in the control group. Finally, the third column considers households that exchanged the vouchers at least every month, and shows that they used LPG stoves to cook around 33 percent more weekly meals than households in the control group. ${ }^{17}$

\section{Insert Table 4}

The ratio $L P G 2$ repeats the analysis considering households that had an LPG cooking stove before participating in the program. The first and second columns show that we cannot confirm that the voucher increased the use of LPG stoves for cooking, both when we consider all the beneficiaries and when we focus on those that at least exchanged the voucher every two months (results are only significant when we use stratified matching). The third column restricts the analysis to households that exchanged the voucher at least every month, and in this case we observe an increase of about 14-18 percent in the use of LPG cylinders for cooking.

To determine which population groups have benefited most from the voucher system, we repeat the previous estimation dividing the households this time into quartiles according to their income. Recall that only those households with an annual income of less than 18,000 nuevos soles can participate in the program. Table 5 presents

\footnotetext{
17 These results are not as high as those reported in Bensch and Peters (2012), who report that the improved stoves introduced in Senegal were used for about 71 percent of the meals in the treatment group. Notice, however, that improved cookstoves use biomass as fuel, which is cheaper but contaminates more.
} 
the impact of the voucher on households in the first and second quartiles. Beneficiary households in the first quartile cooked almost 50-60 percent more of their weekly meals with LPG stoves (10-13 weekly meals) than non-beneficiaries. Households in the second quartile cooked 26 percent more weekly meals (5-6 meals per week) with these stoves than non-beneficiaries. Similar results are found when we restrict the analysis to households that exchanged the vouchers every two months or every month. Interestingly, results for the third and fourth quartiles are not significant (results not shown in the Table for sake of simplicity). This finding is consistent with the observation that households in the third and fourth quartiles use modern fuels more intensely and combine the use of LPG stoves with traditional stoves.

The FISE program may also have modified the habits of the population with regards to boiling water. Families are better able to boil water with LPG stoves because it is cheap and fast, because of the rent effect generated by the voucher, and because they can boil water with LPG stoves and cook with improved stoves. Despite these advantages, our results in Table 6 do not validate this hypothesis. Our estimates for the variable Boiling Water show that the program beneficiaries are no more likely to boil water than are non-beneficiaries. This suggests that a large proportion of the population is aware of the importance of boiling water for consumption, but that the lower "perceived price" of LPG cylinders does not increase this practice. Indeed, 88.2 percent of the households in the control group and 83.1 percent of the treatment group boil their water regularly. However, our results for the variable Boiling Water with LPG Stove show that the voucher increased the probability of households boiling water with this type of stoves by 13-15 percent.

Overall, the results confirm that the FISE does meet three of its objectives: (1) it encourages the replacement of traditional or/and improved stoves with LPG stoves; (2) 
it promotes the use of LPG stoves for cooking, even in those households that were already using an LPG stove before the implementation of the program; and (3) it favors the adoption of LPG cookstoves by low-income households. Other complementary measures evidence how the program has improved the living conditions of the population. Table 7 shows that beneficiary households spend less hours a day cooking, and the time they save is dedicated to child care, perform other domestic activities or engage in a professional activity. The beneficiary population has also expressed the belief that LPG cookstoves help them save time and reduce indoor air pollution.

\section{Insert Table 5}

Insert Table 6

\section{Insert Table 7}

\subsection{Impact on health outcomes}

One of the main justifications for the promotion of LPG stoves is that they moderate indoor toxic emissions and reduce the incidence of respiratory diseases, especially among women and children, who spend more time at home. To test this hypothesis, we seek to determine whether women in beneficiary households have suffered fewer respiratory problems than non-participants. We also consider the number of days that children aged between 3 and 12 did not attend school due to respiratory problems.

Results in Table 8 do not show a significant effect of the voucher on the reduction of respiratory problems in women. Similar results are obtained in Table 9 when the sample is divided into quartiles (for simplicity, we only report results for the first and the second quartiles). Table 10 reports the effects of the program on the number of days 
children did not attend school due to respiratory problems. Again, there is no significant impact.

A possible explanation for these findings is that beneficiary households combine the use of LPG and traditional stoves for economic and/or cultural reasons. Moreover, users of LPG stoves might continue using air polluting fuels for heating. ${ }^{18}$ These results are in line with Beltramo and Levine (2013), who report that six months after the distribution of solar stoves in Senegal beneficiaries did not modify the amount of time they spent cooking over a fire. By contrast, Burwen and Levine (2012) and Bensch and Peters (2012) find an improvement in self-reported health outcomes after the introduction of improved stoves.

\section{Insert Table 8}

\section{Insert Table 9}

\section{Insert Table 10}

\section{Insert Table 11}

Finally, we also study the impact of the program on the prevalence of water-related diseases in children aged between 3 and 12 attending school. We have found evidence that the FISE increases the probability of households boiling their water using LPG stoves, and this could have a positive effect on the children's health. Moreover, during the preparation of the survey, several families reported using LPG cookstoves to boil the water they give the children to drink. To test this hypothesis, the outcome variable

\footnotetext{
${ }^{18}$ Note that our data were collected in April, which is considered the fall season in the Sierra region of Peru. Future studies should perhaps take their measurements of intra-domiciliary pollution at different times of the year to identify more clearly the effects of the program.
} 
we use is the number of days that children in beneficiary households missed school due to episodes of diarrhea. The estimates in Table 11 confirm the existence of a positive effect of the FISE voucher. Specifically, children in beneficiary households reduced school absenteeism by at least 0.28 days a month (around 3 days per year).

\section{Conclusions and policy implications}

In 2012, the Peruvian government created the FISE program, which facilitates access to LPG cookstoves to the most vulnerable sectors of the population by providing them with monthly discount vouchers. Since its introduction, the program has benefited more than 1,500,000 households, in almost all districts across the challenging geography of Peru. The policy is of importance for two main reasons. First, to the best of our knowledge, this is the first nationwide program to have promoted the adoption of LPG cookstoves, considered an intermediate step for the use of other cooking technologies, including natural gas or electricity. And, second, to promote this technology, the government has created a voucher scheme targeting low-income households, managed by regional electricity distributors and supervised by a universal service fund. The characteristics of this scheme make it unique in Latin America and it has been commended by various international organizations.

The FISE has made considerable efforts to target low-income households, avoiding and correcting many of the design problems that typically blight the use of subsidy schemes. A key feature of the program has been the selection of the beneficiary households, based, among other factors, on income, location, and electricity consumption. Additionally, the use of a digital voucher distributed via SMS has been a major factor in the successful implementation of the program and in the avoidance of 
fraudulent practices. The management of the vouchers has been delegated to the regional electricity distributors, and the program relies on many private LPG suppliers which, in recent years, have grown substantially in number. The analysis of this management model should prove insightful to other national regulatory agencies seeking to substitute traditional cookstoves for modern ones.

Here, we have evaluated the effects of the FISE vouchers on a set of outcome variables. By using a data set collected by OSINERGMIN in 2015 in the department of Ayacucho, we have found that the FISE voucher has increased the number of weekly meals cooked on LPG stoves in beneficiary households by seven to eight. This number increases to twelve weekly meals if we consider the lower-income strata of society. These results demonstrate that the program has increased the use of LPG as a cooking fuel, modifying family habits and saving time, which can be used for other domestic or professional purposes. However, our analysis has found no positive effect of the FISE on the respiratory problems of the beneficiary population. One explanation for this is that the users of the vouchers continue to complement traditional stoves with LPG cookstoves and to use wood as heating fuel. The persistence of these habits is a major obstacle to reducing indoor air pollution. According to the "energy ladder" theory, a complete replacement of traditional fuels depends heavily on the socio-economic characteristics of the households as well as on more specific educational and cultural factors.

The results of this study should provide useful guidelines for those drawing up energy policies in developing countries, where major health problems are directly attributable to the use of fuels for cooking and heating. One direct policy implication of the Peruvian experience is that the use of a voucher system can be an effective mechanism to promote the diffusion of modern cooking technologies, and more 
generally for the universalization of essential services. Moreover, the FISE program shows that it is possible to implement subsidy mechanisms that successfully target lowincome households. In this sense, further research should analyze the convenience of establishing the subsidy according to the households' income level. A second policy implication of our analysis is that to improve the health conditions of low-income households, the replacement of traditional cookstoves should be complemented by other actions, including the introduction of improved heating systems and electricity subsidies. ${ }^{19}$

\footnotetext{
${ }^{19}$ For an analysis of the impact that household electrification may have on the reduction of indoor air
} pollution, see Barron and Torero (2017). 


\section{References}

Akpalu, W., I. Dasmani, and P.B. Aglobitse. (2011). Demand for cooking fuels in a developing country: To what extent do taste and preferences matter?. Energy Policy, 39 (10):6525-6531.

Arthur, M. F. S. R., S. Zahran, and G. Bucini. (2010). On the adoption of electricity as a domestic source by Mozambican households. Energy Policy, 38 (11):7235-7249.

Arze del Granado, F.J., D. Coady, and R. Gillingham. (2012). The Unequal Benefits of Fuel Subsidies: A Review of Evidence for Developing Countries. World Development, 40 (11):2234-2248.

Banal-Estañol, A., J. Calzada and J. Jordana (2017). How to achieve full electrification: Lessons from Latin America, Energy Policy, 108, 55-69.

Bansal, M., R.P. Saini, and D.K. Khatod. (2013). Development of cooking sector in rural areas in India---A review. Renewable and Sustainable Energy Reviews, 17:44-53.

Barnes, D.F., Openshaw, K., Smith, K.R., Plas, R.v.d., 1994. What Makes People Cook with Improved Biomass Stoves? A Comparative International Review of Stove Programs. World Bank Technical Paper No 242.

Barnes, D., K. Krutilla and W.F. Hyde (2010). The Urban Household Energy Transition: Social and Environmental Impacts in the Developing World. Routledge.

Barnes, D. F., P. Kumar and K. Openshaw (2012) Cleaner Hearths, Better Homes, New Stoves for India and the Developing Word, Oxford University Press.

Barron, M. and M. Torero (2017) Household electrification and indoor air pollution, Journal of Environmental Economics and Management, 86: 81-92.

Beltramo, T. and D. I. Levine (2013) The effects of Solar Ovens on Fuel Use, Emissions, and Health: Results from a Randomized Controlled Trial. Journal of Development Effectiveness, 5(2), 178-207.

Bensch, G., Peters, J. (2012), A Recipe for Success? Randomized Free Distribution of Improved Cooking Stoves in Senegal, Ruhr Economic Papers, No. 325. 
Bonjour S, Adair-Rohani H,Wolf J, Bruce N, Mehta S, Prüss-Ustün A, et al. (2013) Solid fuel use for household cooking: country and regional estimates for 1980--2010. Environ Health Perspect, 121:784--90.

Burwen, J. and DI. Levine (2012) A rapid Assesment Randomixed-Controlled Trial of Improved Cookstoves in Rural Ghana. Energy of Sustainable Development, 16(3): 328-38.

Calzada, J., S. Iranzo and A. Sanz (2017). Community-Managed Water Services: The Case of Peru, Journal of Environment \& Development, Vol. 26(4) 400-428.

Chaurey, A., Malini, R. and Parimita, M. (2004). Electricity access for geographically disadvantaged rural communities - technology and policy insights. Energy Policy, 32: 16931705

Davis, M. (1998). Rural household energy consumption: The effects of access to electricity--evidence from South Africa. Energy Policy, 26 (3):207-217.

Elias, Rebecca J., Victor, David G., (2005). Energy transition in developing countries: a review of concepts and literature. In: Program on Energy and Sustainable Development, Working Paper. Stanford University: Stanford.

GACC (Global Alliance for Clean Cookstoves). (2014). Guatemala Country Action Plan For Clean Cookstoves and Fuels. Available at http://cleancookstoves.org/resources/284.html

Hanna, R., E. Duflo and M. Greenstone (2016) Up in Smoke: The Influence of Households Behaviour on the Long-Run Impact of Improved Cooking Stoves. American Economic Journal: Economic Policy, 8(1): 80-114.

Hanna, R. and P. Oliva (2015) Moving up the Energy Ladder: The effect of a Permanent Increase in Assets on Fuel Consumption Choices in India. American Economic Review, Papers and Proceedings, forthcoming.

Heltberg, R. (2004). Fuel switching: evidence from eight developing countries. Energy Economics, 26 (5):869-887.

Heltberg, R. (2005). Factors determining household fuel choice in Guatemala. Environment and Development Economics, 10 (03):337-361. 
Hiemstra-van der Horst, G., and A. J. Hovorka. (2008). Reassessing the energy ladder: Household energy use in Maun, Botswana. Energy Policy, 36 (9):3333-3344.

Hosier, R. H., and J. Dowd. (1987). Household fuel choice in Zimbabwe: An empirical test of the energy ladder hypothesis. Resources and Energy 9 (4):347-361.

IEA (International Energy Agency). (2006). World Energy Outlook 2006. Paris: IEA.

Jain, G. (2010). Energy security issues at household level in India. Energy Policy, 38 (6):28352845.

Kojima, M., R. Bacon, and X. Zhou. (2011). Who Uses Bottled Gas? Evidence from Households in Developing Countries. WPS5731. Washington, D.C.: The World Bank.

Leach, G. (1992). The energy transition. Energy Policy, 20 (2):116-123.

Lim, S. S., T. Vos, A. D. Flaxman, G. Danaei et al. (2012). A comparative risk assessment of burden of disease and injury attributable to 67 risk factors and risk factor clusters in 21 regions, 1990--2010: a systematic analysis for the Global Burden of Disease Study 2010. The Lancet, 380 (9859):2224-2260.

Liu, J., G. Daily, P. Erlich, and G. Luck. (2003). Effects of household dynamics on resource consumption and biodiversity. Nature, 421:530-533.

Masera, O. R., B. D. Saatkamp, and D. M. Kammen. (2000). From Linear Fuel Switching to Multiple Cooking Strategies: A Critique and Alternative to the Energy Ladder Model. World Development, 28 (12):2083-2103.

Mehetre, S.A., N.L. Panwar, D. Sharma and H. Kumar (2017) Improved biomass cookstoves for sustainable development: A review, Renewable and Sustainable Energy Review, 73: 672687

Miller, G. and M. Mobarak (2013) Gender Differences in Preferences, Intra-Household Externalities, and the Law Demand for Improved Cookstoves, National Boureau of Economic Research (NBER) Working Paper 18964. 
Nnaji, C. E., E.R. Ukwueze, and J.O. Chukwu. (2012). Determinants of household energy choices for cooking in rural areas: evidence from Enugu State, Nigeria. Continental Journal of Social Sciences 5 (2):1-11.

Ouedraogo, B. (2006). Household energy preferences for cooking in urban Ouagadougou, Burkina Faso. Energy Policy, 34 (18):3787-3795

Pandey, V. L., and A. Chaubal. (2011). Comprehending household cooking energy choice in rural India. Biomass and Bioenergy, 35 (11):4724-4731.

Parikh J. (2011) Hardships and health impacts on women due to traditional cooking fuels: a case study of Himachal Pradesh, India. Energy Policy, 39(12):7587-94.

Pope, D., N. Bruce, M. Dherani, K. Jagoe and E.A. Rehfuess (2017), Real-life effectiveness of improved' stoves and clean fuels in reducing PM25 and CO: Systematic review and metaanalysis, Environment International, 101:7-18.

Puzzolo, E., D. Pope, D. Stanistreet, E.A., Rehfuess and N. Bruce (2016), Clean fuels for resource-poor setting: A systematic review of barriers and enablers to adoption and sustained use, Environmental Research, 146: 218-34.

Ruiz-Mercado I, Masera O, Zamora H, Smith KR. (2011) Adoption and sustained use of improved cookstoves. Energy Policy, 39(12):7557-66.

Smith-Sivertsen, T., Diaz, E., Pope, D., Lie, R. T., Diaz, A., McCracken, J., P. Bakke, B. Arana, K. Smith, and N. Bruce (2009). Effect of reducing indoor air pollution on women's respiratory symptoms and lung function: the RESPIRE Randomized Trial, Guatemala. American Journal of Epidemiology, 170: 211-220.

Vahlne, N. and E.O. Ahlgren (2014), Policy implications for improved cook stove programs. A case study of the importance of village fuel use variations. Energy Policy, Volume 66, March, 484-495.

WHO (2005). World Health Statistics 2005. WHO

WHO. (2006a). Fuel for Life: Household Energy and Health. Geneva: WHO. 
WHO. (2006b). Evaluation of the costs and benefits of household energy and health interventions at global and regional levels. Geneva: WHO.

World Bank (2011), Households Cookstoves, Environment, Health, and Climate Change: A New Look at an Old Problem. International Bank for Reconstruction and Development. 
Table 1. Households' socioeconomic characteristics

\begin{tabular}{|c|c|c|c|c|}
\hline Variable & Total & $\begin{array}{c}\text { FISE } \\
\text { Beneficiaries }\end{array}$ & $\begin{array}{c}\text { FISE Non- } \\
\text { Beneficiaries }\end{array}$ & $|\mathrm{t}|$ \\
\hline \multicolumn{5}{|l|}{ Household variables } \\
\hline Household size & 3.965 & 3.927 & 3.989 & 0.355 \\
\hline Members at meal time & 3.613 & 3.642 & 3.594 & 0.309 \\
\hline Members working & 1.677 & 1.575 & 1.743 & 1.605 \\
\hline Access to social programs & 0.497 & 0.769 & 0.320 & $10.215^{* * *}$ \\
\hline Monthly Income & 648.352 & 390.908 & 800.526 & $6.006^{* * *}$ \\
\hline Monthly Electricity Expenses & 22.342 & 13.614 & 27.914 & $5.385^{* * *}$ \\
\hline Monthly LPG Expenses & 27.336 & 18.832 & 33.701 & $19.548 * * *$ \\
\hline Woman as Head's Household & 0.218 & 0.240 & 0.204 & 0.921 \\
\hline Age of Household's Head & 46.002 & 46.876 & 45.442 & 0.931 \\
\hline Head's Household: Illiteracy & 0.160 & 0.200 & 0.134 & $1.862^{*}$ \\
\hline Head's Household Education: Primary & 0.561 & 0.434 & 0.643 & $4.417^{* * *}$ \\
\hline Head's Household Education: Secondary & 0.227 & 0.149 & 0.279 & $3.229 * * *$ \\
\hline Head's Household Education: Superior & 0.095 & 0.017 & 0.145 & $4.594^{* * *}$ \\
\hline Spouse Education: Primary & 0.452 & 0.300 & 0.550 & $4.585^{* * *}$ \\
\hline Spouse Education: Secondary & 0.118 & 0.050 & 0.161 & $3.638^{* * *}$ \\
\hline Spouse Education: Superior & 0.054 & 0.000 & 0.054 & $3.182^{* * *}$ \\
\hline Maternal Language: Quechua or Aymara & 0.818 & 0.938 & 0.741 & $5.460^{* * *}$ \\
\hline Migration & 0.259 & 0.101 & 0.362 & $6.492^{* * *}$ \\
\hline \multicolumn{5}{|l|}{ Housing variables } \\
\hline Roof: Concrete & 0.243 & 0.069 & 0.343 & $6.757^{* * *}$ \\
\hline Walls: Brick & 0.235 & 0.051 & 0.351 & $7.814^{* * *}$ \\
\hline Floor: Soil & 0.676 & 0.860 & 0.561 & $6.918^{* * *}$ \\
\hline Mobile Phone & 0.715 & 0.682 & 0.736 & 1.22 \\
\hline LPG stove & 0.793 & 0.944 & 0.695 & $6.701^{* * *}$ \\
\hline Improved stove & 0.262 & 0.408 & 0.168 & $5.883^{* * *}$ \\
\hline Traditional stove & 0.496 & 0.453 & 0.523 & 1.479 \\
\hline \multicolumn{5}{|l|}{ Heating Fuels } \\
\hline Only Wood & 0.328 & 0.374 & 0.297 & $1.711^{*}$ \\
\hline Only Modern Fuels & 0.260 & 0.168 & 0.319 & $3.649^{* * *}$ \\
\hline Wood and Modern Fuels & 0.413 & 0.458 & 0.384 & 1.583 \\
\hline
\end{tabular}


Table 2: Descriptive statistics of potential outcome indicators

\begin{tabular}{|c|c|c|c|c|c|c|c|c|c|c|c|c|c|}
\hline Variable & Total & $\begin{array}{c}\text { FISE } \\
\text { Beneficiaries }\end{array}$ & $\begin{array}{c}\text { FISE Non- } \\
\text { Beneficiaries }\end{array}$ & Dif & $|t|$ & $\begin{array}{c}\text { FISE } \\
\text { Beneficiaries } \\
\text { (bi-mensual } \\
\text { change) }\end{array}$ & $\begin{array}{c}\text { FISE Non- } \\
\text { Beneficiaries } \\
\text { and FISE non } \\
\text { users }\end{array}$ & Dif & $|t|$ & $\begin{array}{c}\text { FISE } \\
\text { Beneficiaries } \\
\text { (mensual } \\
\text { change) }\end{array}$ & $\begin{array}{c}\text { FISE Non- } \\
\text { Beneficiaries } \\
\text { and FISE non } \\
\text { users }\end{array}$ & Dif & $|t|$ \\
\hline \multirow{2}{*}{$\begin{array}{l}\text { Proportion of weekly } \\
\text { meals cooked with } \\
\text { LPG (1) }\end{array}$} & $\begin{array}{c}0.6323 \\
(0.0192)\end{array}$ & $\begin{array}{c}0.7071 \\
(0.0241)\end{array}$ & $\begin{array}{c}0.5833 \\
(0.0271)\end{array}$ & \multirow[t]{2}{*}{0.1238} & \multirow[t]{2}{*}{$3.1887 * * *$} & $\begin{array}{c}0.7471 \\
(0.0242)\end{array}$ & $\begin{array}{c}0.5760 \\
(0.0254)\end{array}$ & \multirow[t]{2}{*}{0.1711} & \multirow[t]{2}{*}{$4.2725^{* * *}$} & $\begin{array}{c}0.7698 \\
(0.0253)\end{array}$ & $\begin{array}{c}0.5799 \\
(0.0241)\end{array}$ & \multirow[t]{2}{*}{0.1899} & \multirow[t]{2}{*}{$4.5222^{* * *}$} \\
\hline & $N=453$ & $N=179$ & $N=274$ & & & $N=149$ & $N=304$ & & & $N=125$ & $N=328$ & & \\
\hline \multirow{2}{*}{$\begin{array}{l}\text { Proportion of weekly } \\
\text { meals cooked with } \\
\text { LPG (2) }\end{array}$} & $\begin{array}{c}0.7952 \\
(0.0149)\end{array}$ & $\begin{array}{c}0.7482 \\
(0.0218)\end{array}$ & $\begin{array}{c}0.8369 \\
(0.0200)\end{array}$ & \multirow[t]{2}{*}{-0.0887} & \multirow[t]{2}{*}{$3.0036 * * *$} & $\begin{array}{c}0.7667 \\
(0.0227)\end{array}$ & $\begin{array}{c}0.8144 \\
(0.0196)\end{array}$ & \multirow[t]{2}{*}{-0.0477} & \multirow[t]{2}{*}{1.5726} & $\begin{array}{c}0.7941 \\
(0.0230)\end{array}$ & $\begin{array}{c}0.7958 \\
(0.0192)\end{array}$ & \multirow[t]{2}{*}{-0.0017} & \multirow[t]{2}{*}{0.0547} \\
\hline & $N=360$ & $N=169$ & $N=191$ & & & $N=145$ & $\mathrm{~N}=215$ & & & $N=121$ & $N=239$ & & \\
\hline \multirow{2}{*}{$\begin{array}{l}\text { Family cook with } \\
\text { cough problems }\end{array}$} & $\begin{array}{c}0.4846 \\
(0.0244)\end{array}$ & $\begin{array}{c}0.4823 \\
(0.0384)\end{array}$ & $\begin{array}{c}0.4861 \\
(0.0316)\end{array}$ & \multirow[t]{2}{*}{-0.0037} & \multirow[t]{2}{*}{0.0744} & $\begin{array}{c}0.4577 \\
(0.0420)\end{array}$ & $\begin{array}{c}0.4982 \\
(0.0300)\end{array}$ & \multirow[t]{2}{*}{-0.0405} & \multirow[t]{2}{*}{0.7841} & $\begin{array}{c}0.4711 \\
(0.0456)\end{array}$ & $\begin{array}{c}0.49 \\
(0.0289)\end{array}$ & \multirow[t]{2}{*}{-0.0189} & \multirow[t]{2}{*}{0.3509} \\
\hline & $N=421$ & $N=170$ & $N=251$ & & & $N=142$ & $N=279$ & & & $N=121$ & $N=300$ & & \\
\hline \multirow{2}{*}{$\begin{array}{l}\text { Family cook with } \\
\text { respiratory problems }\end{array}$} & $\begin{array}{c}0.1568 \\
(0.0177)\end{array}$ & $\begin{array}{c}0.1588 \\
(0.0281)\end{array}$ & $\begin{array}{c}0.1554 \\
(0.0229)\end{array}$ & \multirow[t]{2}{*}{0.0034} & \multirow[t]{2}{*}{0.0952} & $\begin{array}{c}0.1549 \\
(0.0305)\end{array}$ & $\begin{array}{c}0.1577 \\
(0.0219)\end{array}$ & \multirow[t]{2}{*}{-0.0028} & \multirow[t]{2}{*}{0.0739} & $\begin{array}{c}0.1488 \\
(0.0325)\end{array}$ & $\begin{array}{c}0.016 \\
(0.0212)\end{array}$ & \multirow[t]{2}{*}{-0.0112} & \multirow[t]{2}{*}{0.2864} \\
\hline & $N=421$ & $\mathrm{~N}=170$ & $N=251$ & & & $\mathrm{~N}=142$ & $N=279$ & & & $\mathrm{~N}=121$ & $N=300$ & & \\
\hline \multirow{2}{*}{$\begin{array}{l}\text { Missed school days } \\
\text { due to respiratory } \\
\text { problems }\end{array}$} & $\begin{array}{c}0.4 \\
(0.0807)\end{array}$ & $\begin{array}{l}0.2667 \\
(.1255)\end{array}$ & $\begin{array}{c}0.5143 \\
(0.1032)\end{array}$ & \multirow[t]{2}{*}{-0.2476} & \multirow[t]{2}{*}{1.5378} & $\begin{array}{c}0.2963 \\
(0.1389)\end{array}$ & $\begin{array}{c}0.4737 \\
(0.0964)\end{array}$ & \multirow[t]{2}{*}{-0.1774} & \multirow[t]{2}{*}{1.084} & $\begin{array}{c}0.32 \\
(0.1497)\end{array}$ & $\begin{array}{c}0.45 \\
(0.0922)\end{array}$ & \multirow[t]{2}{*}{-0.1300} & 0.7826 \\
\hline & $N=130$ & $\mathrm{~N}=60$ & $\mathrm{~N}=70$ & & & $N=54$ & $N=76$ & & & $\mathrm{~N}=50$ & $N=80$ & & \\
\hline Families boiling & $\begin{array}{c}0.8621 \\
(0.0161)\end{array}$ & $\begin{array}{c}0.8315 \\
(0.0281)\end{array}$ & $\begin{array}{c}0.8817 \\
(0.8817)\end{array}$ & -0.0503 & 1.5203 & $\begin{array}{c}0.8311 \\
(0.0309)\end{array}$ & $\begin{array}{c}0.8770 \\
(0.0187)\end{array}$ & -0.0459 & 1.3328 & $\begin{array}{c}0.8226 \\
(0.0344)\end{array}$ & $\begin{array}{c}0.8768769 \\
(0.0180331)\end{array}$ & -0.0543 & 1.4975 \\
\hline & $\mathrm{N}=457$ & $N=178$ & $N=279$ & & & $\mathrm{~N}=148$ & $N=309$ & & & $N=124$ & $N=333$ & & \\
\hline Families boiling & $\begin{array}{c}0.9309 \\
(0.0133)\end{array}$ & $\begin{array}{c}0.9645 \\
(0.0143)\end{array}$ & $\begin{array}{c}0.9015 \\
(0.0215)\end{array}$ & 0.0629 & $2.368^{* *}$ & $\begin{array}{c}0.9793 \\
(0.0119)\end{array}$ & $\begin{array}{c}0.8986 \\
(0.0205)\end{array}$ & 0.0807 & $2.9954^{* * *}$ & $\begin{array}{c}0.9835 \\
(0.0116)\end{array}$ & $\begin{array}{c}0.9046 \\
(0.0190)\end{array}$ & 0.0789 & $2.8159 * * *$ \\
\hline & $N=362$ & $N=169$ & $N=193$ & & & $N=145$ & $\mathrm{~N}=217$ & & & $N=121$ & $\mathrm{~N}=241$ & & \\
\hline $\begin{array}{l}\text { Missed school days } \\
\text { due to diarrhoeal }\end{array}$ & $\begin{array}{c}0.1652 \\
(0.0477)\end{array}$ & $\begin{array}{c}0.0741 \\
(0.0582)\end{array}$ & $\begin{array}{c}0.2459 \\
(0.0726)\end{array}$ & -0.1718 & $1.8148^{*}$ & $\begin{array}{c}0.0213 \\
(0.0213)\end{array}$ & $\begin{array}{c}0.2647 \\
(0.0773)\end{array}$ & -0.2434 & $2.5682^{* *}$ & $\begin{array}{c}0.0233 \\
(0.0233)\end{array}$ & $0.25(0.0733)$ & -0.2267 & $2.3436^{* * *}$ \\
\hline problems & $\mathrm{N}=115$ & $N=54$ & $\mathrm{~N}=61$ & & & $N=47$ & $\mathrm{~N}=68$ & & & $N=43$ & $N=72$ & & \\
\hline
\end{tabular}


Table 3: Probability of receiving the voucher according to the variables selected to create the sample. Logit model.

\begin{tabular}{|c|c|}
\hline Covariates & Coef \\
\hline Log income & $\begin{array}{c}-0.2338 \\
(0.1872)\end{array}$ \\
\hline Mobile phone & $\begin{array}{c}1.1168^{* * *} \\
(0.3457)\end{array}$ \\
\hline Access to social programs & $\begin{array}{c}1.5887^{* * *} \\
(0.3243)\end{array}$ \\
\hline Improved cookStove & $\begin{array}{l}-0.2084 \\
(0.4121)\end{array}$ \\
\hline Traditional cookstove & $\begin{array}{c}-0.8235^{* *} \\
(0.3719)\end{array}$ \\
\hline Electricity monthly expenses & $\begin{array}{c}-0.0433^{* *} \\
(0.0176)\end{array}$ \\
\hline H. Head: primary education & $\begin{array}{c}-0.0137 \\
(0.3685)\end{array}$ \\
\hline H. Head: secondary education & $\begin{array}{c}-0.4414 \\
(0.4514)\end{array}$ \\
\hline Traditional cookstove & $\begin{array}{l}-0.5820 \\
(0.9124)\end{array}$ \\
\hline Floor: soil & $\begin{array}{l}-0.1191 \\
(0.5217)\end{array}$ \\
\hline Wall: no brick & $\begin{array}{l}1.9948 * \\
(1.0606)\end{array}$ \\
\hline Roof: no concrete & $\begin{array}{l}-1.0975 \\
(1.0539)\end{array}$ \\
\hline Maternal language & $\begin{array}{c}0.8680 \\
(0.5353)\end{array}$ \\
\hline Spouse: primary education & $\begin{array}{c}-0.0612 \\
(0.4044)\end{array}$ \\
\hline Spouse: secondary education & $\begin{array}{l}-0.8166 \\
(0.6241)\end{array}$ \\
\hline Constant & $\begin{array}{c}-0.9777 \\
(1.4020) \\
\end{array}$ \\
\hline $\begin{array}{l}\text { Observations } \\
\text { LR chi2(15) } \\
\text { Pseudo R2 }\end{array}$ & $\begin{array}{r}336 \\
131.73^{* * *} \\
0.3051 \\
\end{array}$ \\
\hline
\end{tabular}

*** Significant at $1 \% * *$ Significant at $5 \% *$ Significant at $10 \%$ 


\section{Table 4. Use of cookstoves}

\begin{tabular}{|c|c|c|c|c|c|c|c|c|c|c|}
\hline $\begin{array}{l}\text { Outcome } \\
\text { indicator }\end{array}$ & Estimation & $\begin{array}{c}\text { Treatment Effect } \\
\text { (Whole Data) }\end{array}$ & t-statistic & Observations & $\begin{array}{l}\text { Treatment Effect } \\
\text { (Bi-mensual use } \\
\text { of voucher) }\end{array}$ & t-statistic & Observations & $\begin{array}{c}\text { Treatment Effect } \\
\text { (Mensual use of } \\
\text { voucher) }\end{array}$ & t-statistic & Observations \\
\hline \multirow{3}{*}{ Ratio LPG (1) } & $\begin{array}{c}\text { Nearest } \\
\text { Neighbour }\end{array}$ & $\begin{array}{c}0.3383^{\star \star \star} \\
(0.0747)\end{array}$ & 4.53 & 411 & $\begin{array}{c}0.3413^{\star * \star} \\
(0.0665)\end{array}$ & 5.13 & 411 & $\begin{array}{c}0.3357^{* \star *} \\
(0.0553)\end{array}$ & 6.07 & 411 \\
\hline & Kernel & $\begin{array}{c}0.3634^{* * *} \\
(0.0527)\end{array}$ & 6.89 & 411 & $\begin{array}{c}0.3501^{* * *} \\
(0.0581)\end{array}$ & 6.02 & 411 & $\begin{array}{c}0.3268^{\star * *} \\
(0.0451)\end{array}$ & 7.25 & 411 \\
\hline & Stratification & $\begin{array}{c}0.3814^{\star * *} \\
(0.0499)\end{array}$ & 7.64 & $\begin{array}{c}415 \\
(161-254)\end{array}$ & $\begin{array}{c}0.3509^{* * *} \\
(0.0026)\end{array}$ & 7.77 & $\begin{array}{c}415 \\
(136-279)\end{array}$ & $\begin{array}{c}0.3271^{* * *} \\
(0.0038)\end{array}$ & 8.22 & $\begin{array}{c}415 \\
(113-302)\end{array}$ \\
\hline \multirow{3}{*}{ Ratio LPG (2) } & $\begin{array}{c}\text { Nearest } \\
\text { Neighbour }\end{array}$ & $\begin{array}{c}0.0806 \\
(0.1224)\end{array}$ & 0.66 & 274 & $\begin{array}{c}0.0373 \\
(0.1288)\end{array}$ & 0.29 & 274 & $\begin{array}{c}0.1761^{\star \star} \\
(0.075)\end{array}$ & 2.34 & 274 \\
\hline & Kernel & $\begin{array}{c}0.1111 \\
(0.0801)\end{array}$ & 1.39 & 274 & $\begin{array}{l}0.1050^{\star} \\
(0.0593)\end{array}$ & 1.77 & 274 & $\begin{array}{l}0.1379^{* *} \\
(0.0663)\end{array}$ & 2.08 & 274 \\
\hline & Stratification & $\begin{array}{c}0.1683^{\star \star \star} \\
(0.0753)\end{array}$ & 2.24 & $\begin{array}{c}234 \\
(113-121)\end{array}$ & $\begin{array}{c}0.1443^{\star \star \star} \\
(0.0595)\end{array}$ & 2.42 & $\begin{array}{c}234 \\
(127-107)\end{array}$ & $\begin{array}{c}0.1486^{\star \star *} \\
(0.0568)\end{array}$ & 2.62 & $\begin{array}{c}234 \\
(144-90)\end{array}$ \\
\hline
\end{tabular}

** Significant at $1 \%{ }^{* *}$ Significant at $5 \%{ }^{*}$ Significant at $10 \%$ 
Table 5. Use of cookstoves, by quartiles

\begin{tabular}{|c|c|c|c|c|c|c|c|c|c|c|}
\hline $\begin{array}{l}\text { Outcome } \\
\text { indicator }\end{array}$ & Estimation & $\begin{array}{c}\text { Treatment } \\
\text { Effect } \\
\text { (Whole Data) }\end{array}$ & t-statistic & Observations & $\begin{array}{c}\text { Treatment Effect } \\
\text { (Bi-mensual use } \\
\text { of voucher) }\end{array}$ & t-statistic & Observations & $\begin{array}{c}\text { Treatment Effect } \\
\text { (Mensual use of } \\
\text { voucher) }\end{array}$ & t-statistic & Observations \\
\hline \multirow{3}{*}{$\begin{array}{c}\text { Ratio LPG } \\
\text { (1st quartile) }\end{array}$} & $\begin{array}{c}\text { Nearest } \\
\text { Neighbour }\end{array}$ & $\begin{array}{c}0.4788^{* \star *} \\
(0.0984)\end{array}$ & 4.86 & 100 & $\begin{array}{c}0.5015^{\star * *} \\
(0.0704)\end{array}$ & 7.12 & 100 & $\begin{array}{c}0.4621^{* \star *} \\
(0.0733)\end{array}$ & 6.3 & 100 \\
\hline & Kernel & $\begin{array}{c}0.5623^{\star \star \star} \\
(0.0961)\end{array}$ & 5.85 & 100 & $\begin{array}{c}0.4953^{\star * \star} \\
(0.0735)\end{array}$ & 6.74 & 100 & $\begin{array}{c}0.4778^{\star \star \star} \\
(0.0893)\end{array}$ & 5.35 & 100 \\
\hline & Stratification & $\begin{array}{c}0.6040^{\star * \star} \\
(0.0936)\end{array}$ & 6.45 & $\begin{array}{c}101 \\
(48-53)\end{array}$ & $\begin{array}{c}0.4971^{* * *} \\
(0.0968)\end{array}$ & 5.13 & $\begin{array}{c}101 \\
(58-43)\end{array}$ & $0.4329^{* * *}(.0919)$ & 4.71 & $\begin{array}{c}101 \\
(67-34)\end{array}$ \\
\hline \multirow{3}{*}{$\begin{array}{c}\text { Ratio LPG } \\
\text { (2d quartile) }\end{array}$} & $\begin{array}{l}\text { Nearest } \\
\text { Neighbour }\end{array}$ & $\begin{array}{l}0.2621^{\star *} \\
(0.1206)\end{array}$ & 2.17 & 84 & $\begin{array}{c}0.2907^{\star * *} \\
(0.1116)\end{array}$ & 2.61 & 84 & $\begin{array}{c}0.3112^{\star * *} \\
(0.1021)\end{array}$ & 3.05 & 84 \\
\hline & Kernel & $\begin{array}{l}0.2621^{* *} \\
(0.1314)\end{array}$ & 2 & 84 & $\begin{array}{l}0.2907^{\star \star *} \\
(0.1108)\end{array}$ & 2.62 & 84 & $\begin{array}{c}0.3092^{* \star \star} \\
(0.0984)\end{array}$ & 3.14 & 84 \\
\hline & Stratification & $\begin{array}{c}0.2621^{* \star *} \\
(0.1177)\end{array}$ & 2.23 & $\begin{array}{c}85 \\
(41-44)\end{array}$ & $\begin{array}{c}0.2907^{\star * *} \\
(0.1191)\end{array}$ & 2.44 & $\begin{array}{c}85 \\
(47-38)\end{array}$ & $\begin{array}{c}0.3112^{\star \star \star} \\
(0.1057)\end{array}$ & 2.95 & $\begin{array}{c}85 \\
(54-31)\end{array}$ \\
\hline
\end{tabular}

${ }^{\star * \star}$ Significant at $1 \%{ }^{* \star}$ Significant at $5 \%{ }^{*}$ Significant at $10 \%$ 
Table 6. Households' habit of boiling water

\begin{tabular}{|c|c|c|c|c|c|c|c|c|c|c|}
\hline Outcome indicator & Estimation & $\begin{array}{c}\text { Treatment Effect } \\
\text { (Whole Data) }\end{array}$ & t-statistic & Observations & $\begin{array}{c}\text { Treatment Effect } \\
\text { (Bi-mensual use } \\
\text { of voucher) }\end{array}$ & t-statistic & Observations & $\begin{array}{c}\text { Treatment Effect } \\
\text { (Mensual use of } \\
\text { voucher) }\end{array}$ & t-statistic & Observations \\
\hline \multirow{3}{*}{ Families boiling water } & $\begin{array}{c}\text { Nearest } \\
\text { Neighbour }\end{array}$ & $\begin{array}{c}-0.0380 \\
(0.0493)\end{array}$ & 0.77 & 415 & $\begin{array}{l}-0.0351 \\
(0.0490)\end{array}$ & 0.72 & 415 & $\begin{array}{l}-0.0777 \\
(0.0487)\end{array}$ & 1.6 & 415 \\
\hline & Kernel & $\begin{array}{l}-0.0516 \\
(0.0498)\end{array}$ & 1.04 & 415 & $\begin{array}{l}-0.0409 \\
(0.0496)\end{array}$ & 0.83 & 415 & $\begin{array}{l}-0.0603 \\
(0.0516)\end{array}$ & 1.17 & 415 \\
\hline & Stratification & $\begin{array}{l}-0.0487 \\
(0.0397)\end{array}$ & 1.23 & $\begin{array}{c}415 \\
(161-254)\end{array}$ & $\begin{array}{l}-0.0216 \\
(0.0086)\end{array}$ & 0.49 & $\begin{array}{c}415 \\
(136-279)\end{array}$ & $\begin{array}{l}-0.0460 \\
(0.0469)\end{array}$ & 0.98 & $\begin{array}{c}415 \\
(113-302)\end{array}$ \\
\hline \multirow{3}{*}{$\begin{array}{l}\text { Families boiling water with } \\
\text { LPG Stove }\end{array}$} & $\begin{array}{l}\text { Nearest } \\
\text { Neighbour }\end{array}$ & $\begin{array}{l}0.1818^{* *} \\
(0.0730)\end{array}$ & 2.49 & 276 & $\begin{array}{l}0.1308^{* \star *} \\
(0.0459)\end{array}$ & 2.85 & 276 & $\begin{array}{l}0.1333^{* *} \\
(0.0571)\end{array}$ & 2.34 & 276 \\
\hline & Kernel & $\begin{array}{c}0.0802 \\
(0.0655)\end{array}$ & 1.22 & 276 & $\begin{array}{c}0.1517^{\star * *} \\
(0.0528)\end{array}$ & 2.87 & 276 & $\begin{array}{l}0.0889^{\star} \\
(0.0519)\end{array}$ & 1.71 & 276 \\
\hline & Stratification & $\begin{array}{l}0.1378^{*} \\
(0.0770)\end{array}$ & 1.79 & $\begin{array}{c}334 \\
(113-121)\end{array}$ & $\begin{array}{l}0.1352^{* *} \\
(0.0598)\end{array}$ & 2.26 & $\begin{array}{c}334 \\
(127-107)\end{array}$ & $\begin{array}{c}0.1134^{* * *} \\
(0.0438)\end{array}$ & 2.59 & $\begin{array}{c}334 \\
(144-90)\end{array}$ \\
\hline
\end{tabular}

*** Significant at $1 \%{ }^{* *}$ Significant at $5 \%{ }^{*}$ Significant at $10 \%$ 


\section{Table 7. Households' daily organization and perceptions}

\begin{tabular}{|c|c|c|c|c|}
\hline & $\begin{array}{c}\text { Beneficiaries of } \\
\text { the voucher }\end{array}$ & $\begin{array}{l}\text { Beneficiaries with bi- } \\
\text { mensual use of voucher }\end{array}$ & $\begin{array}{c}\text { Beneficiaries with } \\
\text { monthly use of voucher }\end{array}$ & $\begin{array}{c}\text { Non-beneficiaries } \\
\text { of the voucher }\end{array}$ \\
\hline $\begin{array}{l}\text { Average daily hours dedicated to cook } \\
\text { (households with a LPG cookstove) }\end{array}$ & 2.17 & 2.17 & 2.10 & 1.94 \\
\hline $\begin{array}{l}\text { Households that believe LPG cookstove reduce } \\
\text { cooking time compared to traditional cookstoves }\end{array}$ & $67.5 \%$ & $68.1 \%$ & $72.7 \%$ & $65.5 \%$ \\
\hline $\begin{array}{l}\text { Households that believe LPG cookstove reduce } \\
\text { cooking time compared to improved cookstoves }\end{array}$ & $71.0 \%$ & $69.6 \%$ & $71.4 \%$ & $67.1 \%$ \\
\hline $\begin{array}{l}\text { Use of the time saved with the LPG cookstoves: } \\
\text { Child care } \\
\text { Cleaning activities } \\
\text { Branch activities } \\
\text { Productive activities }\end{array}$ & $\begin{array}{l}34.1 \% \\
50.0 \% \\
35.2 \% \\
43.7 \%\end{array}$ & $\begin{array}{l}30.0 \% \\
51.2 \% \\
32.5 \% \\
44.2 \%\end{array}$ & $\begin{array}{l}34.3 \% \\
56.9 \% \\
35.8 \% \\
47.2 \%\end{array}$ & $\begin{array}{c}29.8 \% \\
48.6 \% \\
20.7 \% \\
35.25 \%\end{array}$ \\
\hline $\begin{array}{l}\text { Households that believe that indoor air pollution } \\
\text { has decreased after adoption LPG cookstove }\end{array}$ & $70.9 \%$ & $67.8 \%$ & $72.8 \%$ & $73.9 \%$ \\
\hline
\end{tabular}


Table 8. Cough and respiratory problems

\begin{tabular}{|c|c|c|c|c|c|c|c|c|c|c|}
\hline $\begin{array}{l}\text { Outcome } \\
\text { indicator }\end{array}$ & Estimation & $\begin{array}{c}\text { Treatment Effect } \\
\text { (Whole Data) }\end{array}$ & t-statistic & Observations & $\begin{array}{c}\text { Treatment Effect } \\
\text { (Bi-mensual use } \\
\text { of voucher) }\end{array}$ & t-statistic & Observations & $\begin{array}{c}\text { Treatment Effect } \\
\text { (Mensual use of } \\
\text { voucher) }\end{array}$ & t-statistic & Observations \\
\hline \multirow{3}{*}{$\begin{array}{l}\text { Cough } \\
\text { problems }\end{array}$} & $\begin{array}{c}\text { Nearest } \\
\text { Neighbour }\end{array}$ & $\begin{array}{c}-0.0254 \\
(0.0776)\end{array}$ & 0.33 & 384 & $\begin{array}{r}-0.0582 \\
(0.0740)\end{array}$ & 0.79 & 384 & $\begin{array}{l}-0.0186 \\
(0.0692)\end{array}$ & 0.27 & 384 \\
\hline & Kernel & $\begin{array}{l}-0.0338 \\
(0.0651)\end{array}$ & 0.52 & 384 & $\begin{array}{r}-0.0281 \\
(0.0732)\end{array}$ & 0.38 & 384 & $\begin{array}{c}0.0033 \\
(0.0673)\end{array}$ & 0.05 & 384 \\
\hline & Stratification & $\begin{array}{c}0.0207 \\
(0.0728)\end{array}$ & 0.28 & $\begin{array}{c}415 \\
(161-254)\end{array}$ & $\begin{array}{l}-0.0605 \\
(0.0590)\end{array}$ & 1.02 & $\begin{array}{c}415 \\
(136-279)\end{array}$ & $\begin{array}{l}-0.0218 \\
(0.0519)\end{array}$ & 0.42 & $\begin{array}{c}415 \\
(113-302)\end{array}$ \\
\hline \multirow{3}{*}{$\begin{array}{l}\text { Respiratory } \\
\text { problems }\end{array}$} & $\begin{array}{c}\text { Nearest } \\
\text { Neighbour }\end{array}$ & $\begin{array}{c}0.0464 \\
(0.0493)\end{array}$ & 0.94 & 384 & $\begin{array}{c}0.0109 \\
(0.0454)\end{array}$ & 0.24 & 384 & $\begin{array}{c}-0.0061 \\
(0.0457)\end{array}$ & 0.13 & 384 \\
\hline & Kernel & $\begin{array}{c}0.0421 \\
(0.0352)\end{array}$ & 1.19 & 384 & $\begin{array}{c}0.0164 \\
(0.0507)\end{array}$ & 0.32 & 384 & $\begin{array}{c}0.0148 \\
(0.0414)\end{array}$ & 0.36 & 384 \\
\hline & Stratification & $\begin{array}{c}0.0410 \\
(0.0426)\end{array}$ & 0.96 & $\begin{array}{c}415 \\
(161-254)\end{array}$ & $\begin{array}{c}0.0149 \\
(0.0414)\end{array}$ & 0.36 & $\begin{array}{c}415 \\
(136-279)\end{array}$ & $\begin{array}{c}0.0062 \\
(0.0441)\end{array}$ & 0.14 & $\begin{array}{c}415 \\
(113-302)\end{array}$ \\
\hline
\end{tabular}

*** Significant at $1 \%{ }^{* \star}$ Significant at $5 \%{ }^{*}$ Significant at $10 \%$ 
Table 9. Cough and respiratory problems, by quartiles

\begin{tabular}{|c|c|c|c|c|c|c|c|c|c|c|}
\hline Outcome indicator & Estimation & $\begin{array}{l}\text { Treatment Effect } \\
\text { (Whole Data) }\end{array}$ & t-statistic & Observations & $\begin{array}{c}\text { Treatment Effect } \\
\text { (Bi-mensual use } \\
\text { of voucher) }\end{array}$ & t-statistic & Observations & $\begin{array}{c}\text { Treatment Effect } \\
\text { (Mensual use of } \\
\text { voucher) }\end{array}$ & t-statistic & Observations \\
\hline \multirow{3}{*}{$\begin{array}{c}\text { 1st quartile } \\
\text { (cough problems) }\end{array}$} & \begin{tabular}{c|} 
Nearest \\
Neighbour
\end{tabular} & $\begin{array}{l}0.0970 \\
(0.1129)\end{array}$ & 0.86 & 91 & $\begin{array}{l}-0.1369 \\
(0.1265)\end{array}$ & 1.08 & 91 & $\begin{array}{l}-0.1660 \\
(0.1188)\end{array}$ & 1.4 & 91 \\
\hline & Kernel & $\begin{array}{c}0.1212 \\
(0.1351)\end{array}$ & 0.90 & 91 & $\begin{array}{r}-0.0816 \\
(0.1259)\end{array}$ & 0.65 & 91 & $\begin{array}{r}-0.1170 \\
(0.1308)\end{array}$ & 0.89 & 91 \\
\hline & Stratification & $\begin{array}{c}0.1387 \\
(0.1273)\end{array}$ & 1.09 & $\begin{array}{c}101 \\
(48-53)\end{array}$ & $\begin{array}{l}-0.0683 \\
(0.1254)\end{array}$ & 0.54 & $\begin{array}{c}101 \\
(58-43)\end{array}$ & $\begin{array}{r}-0.0924 \\
(0.1131)\end{array}$ & 0.82 & $\begin{array}{c}101 \\
(67-34)\end{array}$ \\
\hline \multirow{3}{*}{$\begin{array}{c}\text { 2nd quartile } \\
\text { (cough problems) }\end{array}$} & $\begin{array}{l}\text { Nearest } \\
\text { Neighbour }\end{array}$ & $\begin{array}{c}0.0584 \\
(0.1442)\end{array}$ & 0.41 & 77 & $\begin{array}{l}-0.0752 \\
(0.1393)\end{array}$ & 0.54 & 77 & $\begin{array}{r}-0.0784 \\
(0.1396)\end{array}$ & 0.56 & 77 \\
\hline & Kernel & $\begin{array}{c}0.0584 \\
(0.1304)\end{array}$ & 0.45 & 77 & $\begin{array}{l}-0.0752 \\
(0.1389)\end{array}$ & 0.54 & 77 & $\begin{array}{l}-0.0792 \\
(0.1322)\end{array}$ & 0.60 & 77 \\
\hline & Stratification & $\begin{array}{c}0.0609 \\
(0.1636)\end{array}$ & 0.37 & $\begin{array}{c}85 \\
(41-44)\end{array}$ & $\begin{array}{r}-0.0741 \\
(0.1574)\end{array}$ & 0.47 & $\begin{array}{c}85 \\
(47-38)\end{array}$ & $\begin{array}{r}-0.0774 \\
(0.1563)\end{array}$ & 0.50 & $\begin{array}{c}85 \\
(54-31)\end{array}$ \\
\hline \multirow{3}{*}{$\begin{array}{c}\text { 1st quartile } \\
\text { (respiratory problems) }\end{array}$} & \begin{tabular}{c|} 
Nearest \\
Neighbour
\end{tabular} & $\begin{array}{l}0.0770 \\
(0.1005)\end{array}$ & 0.77 & 92 & $\begin{array}{l}-0.0731 \\
(0.0942)\end{array}$ & 0.78 & 92 & $\begin{array}{l}-0.1258 \\
(0.0884)\end{array}$ & 1.42 & 92 \\
\hline & Kernel & $\begin{array}{c}0.0511 \\
(0.1031)\end{array}$ & 0.5 & 92 & $\begin{array}{r}-0.0646 \\
(0.0875)\end{array}$ & 0.74 & 92 & $\begin{array}{l}-0.1026 \\
(0.0735)\end{array}$ & 1.4 & 92 \\
\hline & Stratification & $\begin{array}{c}0.0945 \\
(0.0829)\end{array}$ & 1.14 & $\begin{array}{c}101 \\
(48-53)\end{array}$ & $\begin{array}{r}-0.0732 \\
(0.1066)\end{array}$ & 0.69 & $\begin{array}{c}101 \\
(58-43)\end{array}$ & $\begin{array}{r}-0.1176 \\
(0.0922)\end{array}$ & 1.28 & $\begin{array}{c}101 \\
(67-34)\end{array}$ \\
\hline \multirow{3}{*}{$\begin{array}{l}\text { 2nd quartile } \\
\text { (respiratory problems) }\end{array}$} & $\begin{array}{l}\text { Nearest } \\
\text { Neighbour }\end{array}$ & $\begin{array}{l}-0.0028 \\
(0.0943)\end{array}$ & 0.03 & 79 & $\begin{array}{c}0.0480 \\
(0.0899)\end{array}$ & 0.06 & 79 & $\begin{array}{r}0.0995 \\
(0.0933)\end{array}$ & 1.07 & 79 \\
\hline & Kernel & $\begin{array}{r}-0.0028 \\
(0.0971)\end{array}$ & 0.03 & 79 & $\begin{array}{c}0.0480 \\
(0.0948)\end{array}$ & 0.51 & 79 & $\begin{array}{r}0.0992 \\
(0.0957)\end{array}$ & 1.04 & 79 \\
\hline & Stratification & $\begin{array}{c}0.0011 \\
(0.1131)\end{array}$ & 0.01 & $\begin{array}{c}85 \\
(41-44)\end{array}$ & $\begin{array}{c}0.0522 \\
(0.1039)\end{array}$ & 0.50 & $\begin{array}{c}85 \\
(47-38)\end{array}$ & $\begin{array}{r}0.1017 \\
(0.0776)\end{array}$ & 1.31 & $\begin{array}{c}85 \\
(54-31)\end{array}$ \\
\hline
\end{tabular}


Table 10. School absenteeism, due to respiratory problems

\begin{tabular}{|c|c|c|c|c|c|c|c|}
\hline $\begin{array}{l}\text { Outcome } \\
\text { indicator }\end{array}$ & Estimation & $\begin{array}{l}\text { Treatment Effect } \\
\text { (Whole Data) }\end{array}$ & t-statistic & Observations & $\begin{array}{c}\text { Treatment Effect } \\
\text { (Bi-mensual use } \\
\text { of voucher) }\end{array}$ & t-statistic & Observations \\
\hline \multirow{3}{*}{ Missing Days } & $\begin{array}{l}\text { Nearest } \\
\text { Neighbour }\end{array}$ & $\begin{array}{c}-0.06 \\
(0.1016)\end{array}$ & -0.59 & 104 & $\begin{array}{l}-0.0638 \\
(0.1081)\end{array}$ & -0.59 & 104 \\
\hline & Kernel & $\begin{array}{l}-0.1432 \\
(0.1765)\end{array}$ & -0.57 & 94 & $\begin{array}{r}-0.0721 \\
(0.1291)\end{array}$ & -0.56 & 104 \\
\hline & Stratification & $\begin{array}{r}-0.1173 \\
(0.1217)\end{array}$ & -0.96 & $\begin{array}{c}64 \\
(40-24)\end{array}$ & $\begin{array}{r}-0.0729 \\
(0.0814)\end{array}$ & -0.90 & $\begin{array}{c}72 \\
(47-25)\end{array}$ \\
\hline
\end{tabular}

*** Significant at $1 \%{ }^{* \star}$ Significant at $5 \%{ }^{*}$ Significant at $10 \%$ 
Table 11. School absenteeism, due to diarrhea

\begin{tabular}{|c|c|c|c|c|c|c|c|}
\hline $\begin{array}{c}\text { Outcome } \\
\text { indicator }\end{array}$ & Estimation & $\begin{array}{c}\text { Treatment Effect } \\
\text { (Whole Data) }\end{array}$ & t-statistic & Observations & $\begin{array}{c}\text { Treatment Effect } \\
\text { (Bi-mensual use } \\
\text { of voucher) }\end{array}$ & t-statistic & Observations \\
\hline \hline & Nearest & $\begin{array}{c}-0.28^{* * *} \\
(0.1021)\end{array}$ & -2.74 & 104 & $\begin{array}{l}-0.2979^{* * *} \\
(0.1081)\end{array}$ & -2.75 & 104 \\
& Neighbour & $-0.2968^{* * *}$ & -2.20 & 94 & $\begin{array}{l}-0.2080^{* *} \\
(0.1028)\end{array}$ & -2.02 & 104 \\
& Kernel & $(0.1199)$ & & 78 & $-0.2224^{* *}$ & $-2,09$ & 87 \\
& Stratification & $-0.2725^{\star * *}$ & -2.11 & $(40-38)$ & $(0.1063)$ & $(47-40)$ \\
\hline
\end{tabular}

${ }^{\star \star *}$ Significant at $1 \%{ }^{* \star}$ Significant at $5 \%{ }^{*}$ Significant at $10 \%$ 


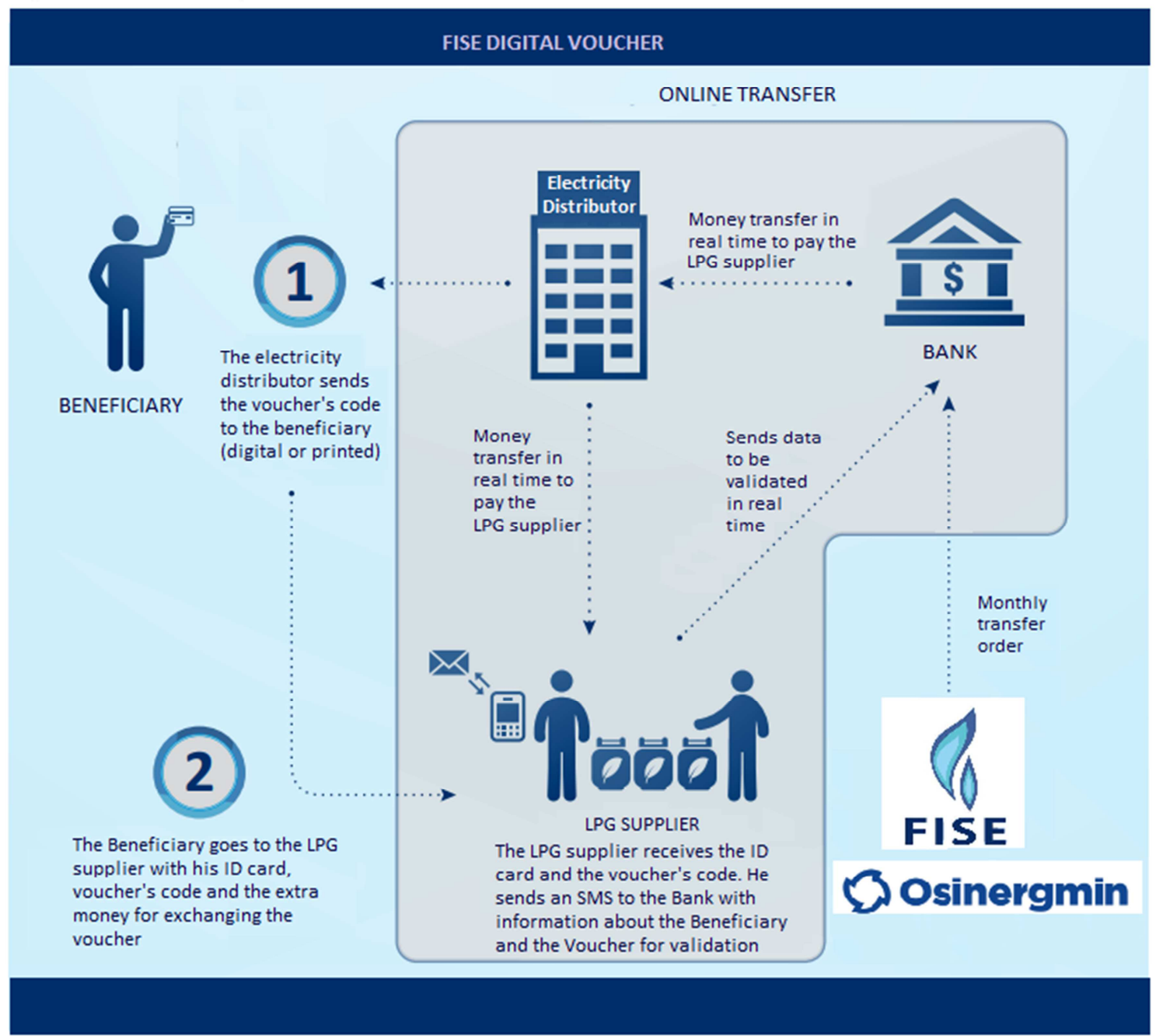

Note: The figure has been simplified for exposition purposes.

Source: Memoria FISE 2016 
Figure 2. Beneficiary households

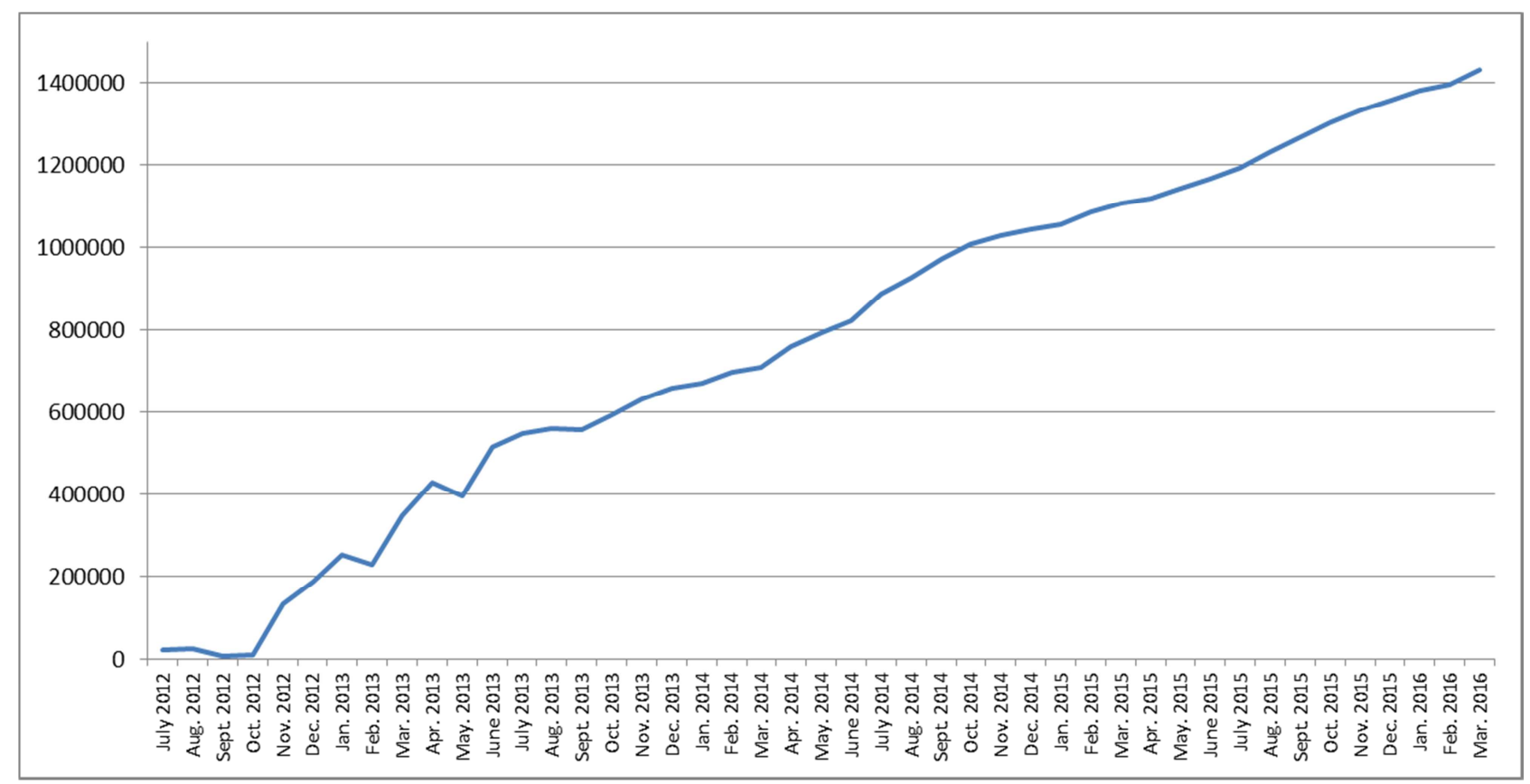


Figure 3. LPG Authorized Agents

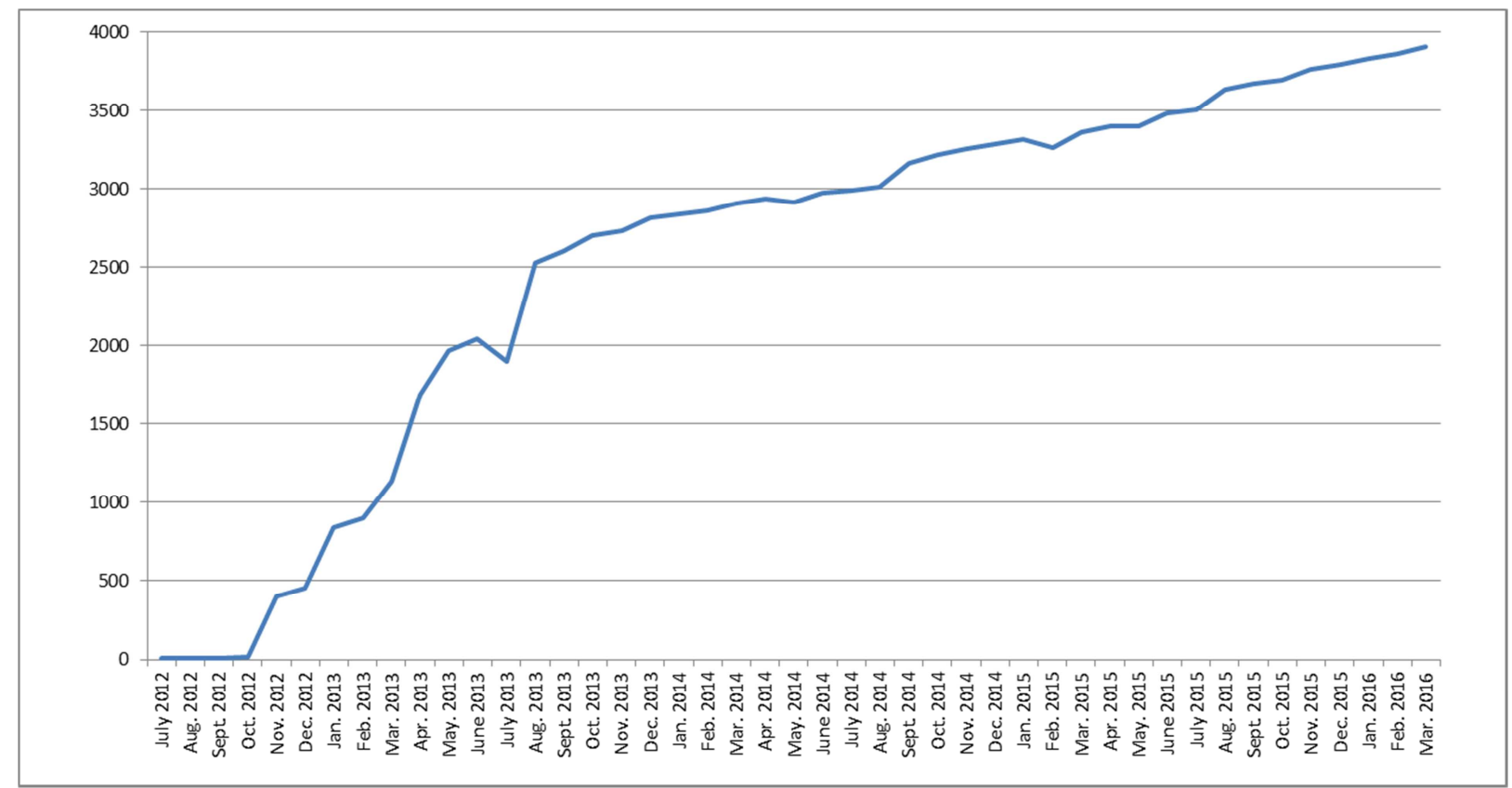


Figure 4.Propensity score

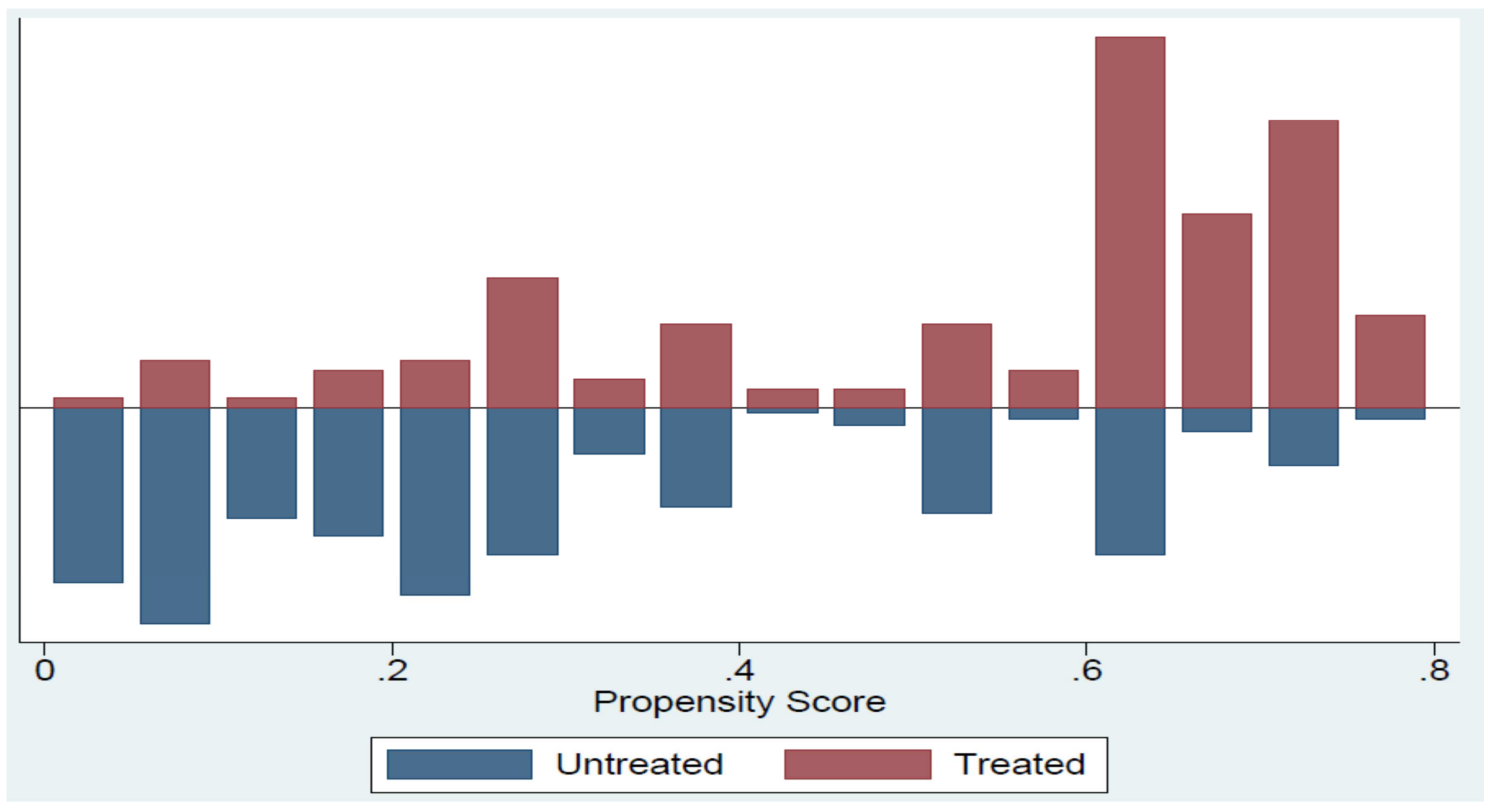

